\title{
CONTROL OF AIR POLLUTION THROUGH THE ASSERTION OF PRIVATE RIGHTS
}

\author{
JULIAN ConRad JUERGENSMEyer*
}

Air pollution is clearly one of the major social problems confronting contemporary American society. Yet the United States is still without an effective federal pollution control program, and those state and local control programs that do exist are largely ineffective. Until government regulation is able to keep the expulsion of air contaminants within tolerable limits, it will be necessary for those seeking to control air pollution to rely upon the assertion of private rights. In this article the author discusses the principal causes of action available to the private pollution controller, and concludes that, although traditional legal concepts may provide the framework for obtaining adequate relief in individual cases, the overall pollution control consequences of private actions are at best piecemeal and not a substitute for effective government regulation.

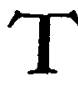
HE air corridors above the United States have been so polluted in our short history as an industrial nation that by 1960 nearly one-fourth of the American population lived in cities suffering major air pollution problems. ${ }^{1}$ The serious plight of these citizens is revealed by the statistical conclusion that their chance of dying from respiratory ailments between 50 and 70 years of age is double that of fellow citizens living in relatively non-polluted areas. ${ }^{2}$ In addition to damage to health, the damage caused by air pollution to property in the United States probably exceeds eleven billion dollars each year, or approximately $\$ 65$ per American citizen. ${ }^{3}$

The magnitude of the problem would seem to clearly necessitate governmental action. Yet in 1967, the nation is still without an effective federal control program, and state and local control pro-

- A.B. 1959, Duke University; C.E.P. 1960, Bordeaux (France); LL.B. 1963, Duke University; Assistant Professor of Law, Indiana University. The author expresses his gratitude for the research assistance of Miss Anita Morse, Indiana School of Law, Class of 1968 .

I E. EDELson \& F. WARschofsky, PoIsons in the AIR 24 (1966).

Id. at 26.

Id. at 110 . 
grams are with very few exceptions non-existent, ineffective, or poorly enforced. 4

The purpose of this article is to suggest that until governmental action is effective to keep the expulsion of air pollutants within tolerable limits, there are private rights which may under some circumstances be asserted by individuals to protect themselves from or obtain redress for injuries to their health and damage to their property. Assertions of private rights have control consequences ${ }^{5}$ in

- U.S. Dep't of Health, Education, and Welfare, a Digest of State Air Pollu. TION LAws ii (Public Health Service Pub. No. 711, 1966 ed. Thereinafter cited as HEW DIGEST], shows that 26 states provided legislative controls over air pollution as of 1966. In general, the acts define air pollution as "the presence in the outdoor atmosphere of one or more air contaminants in sufficient quantities and of such characteristics and duration as to be injurious to human, plant, or animal life or to property . ..." DEL. CODE ANN. tit. 7, $\$ 6202$ (a). Violation of the air polution regulations is usually punishable by fine. E.g., D.C. Code ANN. \$6.803 (1961); KY. REv. STAT. \$77.255 (1962). However, Florida allows injunction proceedings to be initiated in the case of noncompliance, FLA. STAT. ANN. $\$ 403.18$ (Supp. 1966), and the maintenance of a nuisance in Iowa is punishable by fine, imprisonment not to exceed one year, and/or abatement of the nuisance, IOWA CODE ANN. $\$ 657.3$ (1950). Certain of the acts provide for tax exemptions or rapid amortization of air pollution control devices. CAL. REv. \& TAX. Code $\S \S 17226,24372$ (West 1956); MICH. CoMP. LAws $\$ \S 336.1-8$ (1967); N.H. Rev. STAT. ANN. \$149:5-a (1964). Other acts, such as those of Minnesota and Mississippi, merely authorize municipalities to enact air pollution regulations. MINN. STAT. ANN. $\$ \S 461.07-08$ (1963), 144.12 (14) (Supp. 1966); Miss. Code ANN. \$§ 3374-124, -150 (1956). Most of the acts provide some method for obtaining variances or relief from strict application. E.g., R.I. GeN. Laws ANN. $\$ \S 23-25-15$ (a) to (c) (Supp. 1956); TEXAs Rev. Civ. STAT. art. 4477-4 (Supp. 1966).

The most glaring deficiency to be seen in a review of state air pollution control regulations is the lack of any consideration of the interstate implications of air pollution emissions. The Clean Air Act $\$ \S 102-04,42$ U.S.C. $\$ \S 1857 a-c$ (1964), attempted to alleviate this problem by encouraging the establishment of interstate cooperation in research and technical assistance through the use of federal grants. However, the present federal legislation contains no effective prohibition controls. Section 105 of the Act, which provides for the abatement of air pollution, is permissive in nature and may only be utilized upon the request of a state governor. 42 U.S.C. $\$ 1857$ d (1964).

The Air Quality Act of 1967, Pub. L. No. 90-148, was signed by President Johnson on November 21, 1967. Its operation is modeled on the Water Quality Act, 33 U.S.C. $\$ 466$ (1964), and gives the states specified time limits within which they must adopt air quality standards, $\S 108(\mathrm{c})$, after issuance of air quality criteria by the Secretary of HEW, $\S 107$ (b), subject to judicial proceedings in a federal court in the case of failure to enact or enforce such standards, $\S 108(\mathrm{~g})$. However, the major amendment to the Air Quality Act which was sought in the original Senate bill, S. 780, 90th Cong., lst Sess. (1967), which would have established national uniform emission standards for specific pollutants, was deleted from both the Senate and House versions because of strong opposition from various industry groups including coal and steel producers and electric power companies. 25 CoNG. Q. WEEkLY REPORT 1287 (1967). The bill, as passed, does not, therefore, provide the solution which is necessary, but the additional enforcement powers which have been given to the Secretary of HEW are an improvement.

5 "There are many legal paths to the goal of the elimination of air pollution in this 
that they lead to injunctions against future pollution or in that damages obtained from polluters make the expulsion of pollutants expensive and thereby economically motivate polluters to control pollution. ${ }^{6}$

The approach taken in this article is to examine the causes of action which may be used by the would-be pollution controller. Three principal theories of action can be distinguished upon which the individual may ground his assertion of private rights: (l) nuisance and (2) trespass, which are generally used in connection with damage to property, and (3) negligence, which is primarily used in connection with injury to person. A fourth theory-strict liabilitywill also be discussed. ${ }^{7}$

country. One method-widely overlooked by the bar-is the bringing of a civil action against the polluters for lung damage or other injury caused by the inhalation of the polluting substance." Rheingold, Lawsuit as Social Action?, 2 Trist, Oct.-Nov., 1966, at 11 .

Others have been less optimistic when considering private rights and air pollution control and have rejected the concept as having no important control potential: "While air pollution, particularly smoke, was not a nuisance per se at common law, evidence in each particular case could show that it was in fact a nuisance. Despite this abstract protection of the common law against air pollution, private litigation for relief from the effects of such pollution has been unsuccessful as a means of control. The remedy of injunction is so drastic as to limit its use to extreme cases, and the collection of damages where a plaintiff is successful is often merely a recurrent fee that the defendant is willing to pay. The failure of individual action as an answer to the problem is not at all surprising in the face of the following facts of legal life: (a) The suffering of any given individual has often been neither significant nor irreparable, nor readily enough demonstrable in terms of dollars of damage to satisfy the doctrines that limit the granting of effectively deterrent kinds of relief; (b) The difficulty and cost of investigating and of properly proving, from among all possible sources, the source, or sources responsible for a given injury have been too far out of proportion to the likely benefits of successful litigation; (c) In an urban setting, pollution may stem from innumerable sources, many of which, although contributing to the harm complained of, constitute no readily identifiable source of injury." Rogers \& Edelman, Air Pollution Control Legislation, 2 AIR Pollunion 428, 430-31 (A. Stern ed. 1962).

- This is similar to the argument made by many economists when they suggest that pollution be controlled by taxing it. The taxation approach seems particularly wellsuited to water pollution because the tax money can be used to purify the water and the amount of the tax can be determined by the cost of correcting the pollution. Where air pollution is concerned, however, the problem is not so simple since there is at present no effective way of cleansing the air once it is polluted. Thus, the primary relation of a tax on air pollution to the economic consequences of the pollution would be to the damage it causes. See Mills, Economic Incentives in Air Pollution Control, in The Economics of AIr Pollumon 40 (H. Wolozin ed. 1966).

"Rheingold lists as "causes of action" for personal injury due to air pollution: (1) occupier adjacent to factory, (2) premises liability, (3) person off premises, (4) contractors; maintenance companies, (5) gas dealers, (6) products liability, (7) motor vehicles, (8) occupational diseases and other statutes, (9) action by urban residents, (10) action against government, (11) products liability action against automobile manufacturers, and (12) medical malpractice. Rheingold, Civil Cause of Action for Lung 
Damage Due to Pollution of Urban Atmosphere, 33 BrookLyN L. REv. 17, 24-30 (1966). It would seem that this is not a classification by "causes of action" but by potential plaintiffs and/or potential defendants.

As Rheingold's discussion itself reveals, these plaintiffs will choose to ground their theory in negligence, trespass, and/or nuisance in most instances. Id. Rheingold's discussion does suggest two additional causes or theories of action-as those terms are used in this article-namely, statutory liability and products liability. Id. at 26, 28-30. For a discussion of the former see note 87 infra and accompanying text. As for the latter, the expanding field of products liability presents a specie of cause of action which, although part of the general field of tort and contract actions, represents a hybrid cause with unique attributes. A thorough discussion of the elements of a products liablity case is beyond the scope of this article. For a general treatment see 2 F. HARPER \& F. JAMEs, THE LAW OF TORTS $\$$ 28.12-.14 (1956).

It is important to note, for the purposes of this article, that the characterization of a products liability action as one based on express or implied warranty, fitness for the particular purposes of the buyer and merchantable quality, carries with it the problems of basing an action $e x$ contractu. In such an instance the limitations on the cause of action would differ from one based in tort. Privity of contract might well become a necessary basis of the action, and the recoverable damages would differ from those in a tort action. See, e.g., F.H. Woodruff \& Sons v. Brown, 256 F.2d 391 (5th Cir. 1958); Stanley v. Chastek, 34 Ill. App. 2d 220, 180 N.E.2d 512 (1962); W. Prosser, LAW OF TORTs $\$ 93$ (3d ed. 1964) [hereinafter cited as PROsser]. It is apparent in the cases collected that there is no clear authority as to the applicability of contract or tort limitations in products liability actions. The plaintiff in an air pollution suit should be well aware of this problem before choosing a possible attack which offers no alternative grounds of recovery.

The developing area of products liability which offers the pollution controller an enhanced method of attack is the concept of strict liability. See generally F. HARPER \& F. JAMES, supra at $\$ \S 28.15-.28$; ProssER $\$ 97$. The major difference in this concept is that, once having established the defendant's relationship to the product, the defective and unreasonably dangerous condition of the product, and the existence of a proximate causal connection between such condition and the plaintiff's injuries or damages, there is no necessity to prove negligence on the part of the defendant. Greenman v. Yuba Power Prods., Inc., 59 Cal. 2d 57, 377 P.2d 897, 27 Cal. Rptr. 697 (1962). This position has been accepted by the REstatement (SECOND) OF TORTS \$ 402(A) (1965), which provides:

“(1) One who sells any product in a defective condition unreasonably dangerous to the user or consumer or to his property is subject to liability for physical harm thereby caused to the ultimate user or consumer, or to his property, if (a) the seller is engaged in the business of selling such a product, and (b) it is expected to and does reach the user or consumer without substantial change in the condition in which it is sold. (2) The rule stated in Subsection (1) applies although (a) the seller has exercised all possible care in the preparation and sale of his product, and (b) the user or consumer has not bought the product from or entered into any contractual relation with the seller."

Extensions of the strict liability rule have been made into almost every area of possible products liability on the part of manufacturers and sellers. See Chapman Chem. Co. v. Taylor, 215 Ark. 630, 222 S.W.2d 820 (1949) (crop damage caused by a chemical spray manufactured by the defendant and utilized by another party). The use of this theory as a basis of air pollution control through suits against manufacturers and sellers of offending products may well prove to be a major means of successful control. See Emroch, Pleading and Proof in a Strict Products Liability Case, 525 INs. L.J. 581 (1966). Again the problems of the statute of limitations, types of recoverable damages, burden of proof, and, in some cases, choice of laws, indemnification, and contribution must be emphasized as being of prime consideration in choosing the type of action. See, e.g., George v. Douglas Aircraft Co., 332 F.2d 73 (2d Cir.), cert. denied, 


\section{NuISANCE}

Air pollution was labeled a nuisance at least as early as 1611 when an English court affirmed the granting of an injunction and damages in William Aldred's Case $e^{8}$ on a showing that the plaintiff's air had been corrupted by defendant's hog sty. The defendant was found to be committing a nuisance even though he pleaded that the building of a house for hogs was necessary for the sustenance of man and that one ought not to have so delicate a nose that he cannot bear the smell of hogs. The court reached its decision for plaintiff by reasoning that since the law gave an action for light and air, " $a$ fortiori an action lies in the case at Bar for infecting and corrupting the air."g

Since at common law the gravamen of an action for nuisance lay in the interference with a right to use property, we can conclude from William Aldred's Case that a property owner has a right to have the air above his property free from infection and corruption. However, when a court is called upon to protect this right it finds itself wielding a two-edged sword, namely, the right of both parties to use their property as they wish-subject only to an identical right in the other party. As the Supreme Court of Oklahoma has said, the law of private nuisance is "a definition of the dividing line between the right of any owner to use his property as he so desires and the recognition of that right in another." 10

Since our nation has until recently been unable to comprehend that any of its resources-much less pure air-are exhaustible, and since even today the full impact of the effects, causes, and control of air pollution is poorly understood by most lawyers and judges as well as laymen, it is not surprising to discover that an individual is confronted with serious obstacles when he asserts his right to be free from air pollution through a nuisance action. An examination of the leading cases in which air pollution was alleged to constitute a

379 U.S. 904 (1964); Keckler v. Brookwood Country Club, 248 F. Supp. 645 (N.D. IIl. 1965); Suvada v. White Motor Co., 32 I11. 2d 612, 210 N.E.2d 182 (1965).

An infrequently used additional cause of action which is available to the victim of air pollution is a suit in inverse condemnation where the plaintiff's property has been invaded by pollution emanating from the activities of a state, municipality, or even a private corporation having the power of eminent domain, and plaintiff has not received just compensation. See, e.g., Richards v. Washington Terminal Co., 233 U.S. 546 (1914); Donaldson v. Bismarck, 71 N.D. 592, 3 N.W.2d 808 (1942).

877 Eng. Rep. 816 (K.B. 1611).

Id. at 821 .

${ }^{10}$ Roberts v. C.F. Adams \& Son, 199 Okla. 369, 371, 184 P.2d 634, 637 (1947). 
nuisance leads to the conclusion that the courts, while paying lip service to the landowner's right to pollution-free air, have nevertheless recognized a right to do at least some polluting of the air.

The Supreme Court of Georgia in Holman v. Athens Empire Laundry Company, ${ }^{11}$ made a classic exception-gobble-up-the-rule statement on the subject:

Every person has the right to have the air diffused over his premises, whether located in the city or country, in its natural state and free from artificial impurities.

(a) By air in its natural state and free from artificial impurities is meant pure air consistent with the locality and character of the community.

(b) The pollution of the air, so far as reasonably necessary to the enjoyment of life and indispensable to the progress of society, is not actionable.

(c) The privilege of use incident to the right of property must not be exercised in an unreasonable manner, so as to inflict injury upon another unnecessarily. ${ }^{12}$

Most courts have reached the result of allowing air pollution as long as the pollution is not unreasonable or unnecessary by "balancing the equities" between property-owning litigants asserting their right to use their property as they wish. The courts have been especially impressed by the need to "balance equities" when the would-be private pollution controller asks for an injunction instead of, or in addition to, damages.

The oft-cited cases of Madison v. Ducktown Sulphur, Copper \& Iron Company ${ }^{13}$ and Hulbert v. California Portland Cement Company ${ }^{14}$ demonstrate the approach in air pollution cases of a court committed to the necessity and desirability of balancing the equities and a court which rejects the balancing concept.

In Ducktown the Supreme Court of Tennessee had before it bills grounded in nuisance and based on damages suffered by com. plainants from air pollutants discharged by the plants of the de. fendants. The court recognized that the general effect of the pollutants made it impossible for complainants to raise and harves

\footnotetext{
11149 Ga. 345, 100 S.E. 207 (1919).

12 Id. (court syllabus). It is interesting to note that American Jurisprudence, wher stating the rule for which it cites this case, states: "But this right of pollution mus not be exercised in an unreasonable manner so as to inflict injury upon another un necessarily ...." 39 AM. JUR. Nuisances $\$ 53$ (1942) (emphasis added).

18113 Tenn. 331, 83 S.W. 658 (1904).

14 161 Cal. 239, 118 P. 928 (1911).
} 
their customary crops, largely destroyed the timber on their properties, and prevented them "from using and enjoying their farms and homes as they did prior to the inauguration of these enterprises." 15

Yet, in spite of these serious consequences, the court, balancing the equities in favor of the defendants, declined to grant injunctive relief. ${ }^{16}$ Since it was impossible for defendants to reduce their ores in a different manner, or remove to a more remote location, ${ }^{17}$ the court concluded that such relief would compel defendants to stop operating their plants, make their properties practically worthless, ${ }^{18}$ destroy almost one-half the county tax base, and cause 10,000 people to leave their homes in search of employment. ${ }^{19}$ Thus, the court reasoned:

In order to protect by injunction several small tracts of land, aggregating in value less than $\$ 1,000$, we are asked to destroy other property worth nearly $\$ 2,000,000$, and wreck two great mining and manufacturing enterprises .... The result would be practically a confiscation of the property of the defendants for the benefit of the complainants-an appropriation without compensation.... We appreciate the argument based on the fact that the homes of the complainants who live on the small tracts of land referred to are not so comfortable and useful to their owners as they were before they were affected by the smoke complained of, and we are deeply sensible of the truth of the proposition that no man is entitled to any more rights than another on the ground that he has or owns more property than that other. But in a case of conflicting rights, where neither party can enjoy his own without in some measure restricting the liberty of the other in the use of property, the law must make the best arrangement it can between the contendirg parties, with a view to preserving to each one the largest measure of liberty possible under the circumstances. We see no escape from the conclusion in the present case that the only proper decree is to allow the complainants a reference for the ascertainment of damages, and that the injurction must be denied to them . . . . ${ }^{20}$

In Hulbert the plaintiffs sought an injunction requiring the defendant to cease discharging cement dust, which had been falling

15113 Tenn. at 340, 83 S.W. at 659 .

10 Id. at 366, 83 S.W. at 666 .

17 Id.

${ }^{18}$ Id. at 343,83 S.W. at 660 .

${ }^{10} \mathrm{Id}$. at $366,83 \mathrm{S.W}$. at 666 .

20 Id. 
on their properties. The dust, it seems, not only filtered through the plaintiffs' homes, but also formed an "opaque semi-cemented encrustation upon the upper sides of all exposed flowers and foliage," and particularly upon the citrus fruit grown by plaintiffs. ${ }^{21}$ Unlike ordinary dust, these cement deposits were not capable of being "dissipated by the strongest winds, nor washed off through the action of the most protracted rains." 22 In light of these conditions, the lower court found the value of plaintiffs' citrus fruit was decreased, that the constant presence of the dust on the leaves and limbs of the trees made cultivation and harvesting of the crop more expensive, and that the presence of the dust in plaintiffs' homes made life less pleasant. ${ }^{23}$

The defendant made the usual defenses that he was doing all that could be done to keep the dust from being discharged, that damages were sufficient to compensate plaintiffs for their injury, and after stressing the size of its payroll and resulting benefit to the community, contended for the rule that "the resulting injuries must be balanced by the court, and ... where the hardship inflicted upon one party by the granting of an injunction would be very much greater than that which would be suffered by the other party if the nuisance were permitted to continue, injunctive relief should be denied."24

After discussing and citing numerous cases pro and con of the question of balancing equities in such cases, the Supreme Court of California affirmed the granting of the injunction. The writer of the court's opinion, Justice Melvin, quoted with approval one of the strongest rejections of the balancing doctrine:

'Of course great interests should not be overthrown on trifling or frivolous grounds, as where the maxim de minimis non curat lex is applicable; but every substantial, material right of person or property is entitled to protection against all the world. It is by protecting the most humble in his small estate ... that the poor man is ultimately enabled to become a capitalist himself. If the smaller interest must yield to the larger, all small property rights, and all small and less important enterprises, industries, and pursuits would sooner or later be absorbed by the large, more powerful few; and their development to condition of great value and

\footnotetext{
21161 Cal. at 244, 118 P. at 930.

${ }^{23} \mathrm{Id}$.

38 Id.

34 Id. at 246, 118 P. at 931.
} 
importance, both to the individual and the public, would be arrested in its incipiency.'25

Although no attempt has been made to count the cases, it is submitted that the Ducktown position is that most frequently taken by the courts. For even the most zealous of pollution controllers to reject the Ducktown position would be inconsistent and selfdefeating, since his ultimate concern is protecting society from the harm caused by individuals using their property contrary to the public interest. What is regrettable and unacceptable from a pollution control standpoint about Ducktown is not that the court determined its action by a greatest good to the greatest number standard, but that it did not consider possible harm from the air pollution in question to thousands and even millions of citizens other than the immediate complainants. Only when this additional consideration is added to the scale can there be a true balancing of the equities. ${ }^{26}$

Certain technical aspects of the law of nuisance may keep the

${ }^{25} \mathrm{Id}$, at 251, $118 \mathrm{P}$. at 933, quoting Judge Sawyer in Woodruff v. North Bloomfield Gravel Mining Co., 18 F. 753, 807 (C.C.D. Cal. 1884).

${ }^{20}$ In Keeton \& Morris, Notes on "Balancing the Equities," 18 Texas L. REv. 412, 420 (1940), the authors take the position that the plaintiff is usually secking an injunction in order to exact the highest price possible for his property. The note discusses the decision in Ducktown, concluding that the community livelihood which was dependent upon the industry's continuance was justification for not allowing the injunction. Id. The writers do speculate, however, that a better remedy than common Iaw actions for damages should perhaps be devised to protect the interests of the plaintiffs. Id.

Even absent a better remedy, Keeton and Morris suggest that compensatory relief is usually the proper solution and, if deterrence is the motivating factor for granting relief, punitive damages would be more likely to produce desirable results than an injunction. Id. at 424. They argue that "if the defendant is conducting an enterprise of social value exceeding the social value of the plaintiff's interests, the common weal may best be served by permitting the defendant's plant to remain undisturbed, requiring him to compensate the plaintiff for his financial losses, and punishing him sufficiently for mis-locating his plant to discourage similar future wrongdoing. After all, we do not condemn to death the child conceived illicitly, nor is it always wise to destroy the factory which should not have been built. Perhaps in a community whicls has too many factories, destruction of a few may work a social benefit rather than a social harm. But if industrial birth control is needed, injunction for nuisance can hardly be counted on to do the job." Id. at 425 .

The analogy between factories that should not have been built and illegitinate children is at best contrived. Absent proper zoning and pollution control laws, and given the complexity of obtaining punitive damages, injunctions may be the only way to control the pollution. See note 49 infra for a discussion of punitive damages. For an example of judicious use of an injunction see Renken v. Harvey Aluminium, Inc., 226 F. Supp. 169 (D. Ore. 1963), discussed in notes 64-69 infra and accompanying text. 
private pollution controller from obtaining damages-much less an injunction. For example, if the nuisance is labeled "public" rather than private, in order to prevail the objector must demonstrate that he has or will suffer some "special injury" other than that which the general public will suffer. Otherwise only the state through its agents or officials may proceed. ${ }^{27}$ If the party complaining of the pollution can convince the court that the pollution is one which affects a single individual or a determinate number of persons in the enjoyment of some right not common to the public, then theoretically at least, he need not worry about showing special damage since the nuisance will be labeled "private." Since public nuisances are defined as those which "affect an interest common to the general public, rather than peculiar to one individual or several,"28 and since the "special damage" must be different in kind from that suffered by the general public and not just different in degree, ${ }^{29}$ it is at least arguable that most instances of air pollution are public nuisances rather than private due to the wide diffusion of air pollutants through shifting winds and storms. Thus, if the courts persist in their "kind" rather than "degree" distinction, the increased understanding of the widespread effects of what has previously been thought of as localized air pollution may render the private nuisance action against air pollution less frequently available than in the past. $^{30}$

If the private pollution controller does succeed in having the nuisance of which he complains labeled "private," there may be

27 "As a general rule a public nuisance gives no right of action to any individual but must be abated by process instituted in the name of the state." Holman v. Athens Empire Laundery Co., 149 Ga. 345, 349, 100 S.E. 207, 209 (1919). See also Prosser, Private Action for Public Nuisance, 52 VA. L. REv. 997 (1966). Since the complainer of a private nuisance must show an interference with the use and enjoyment of land, the only type of nuisance action available to many injured by air pollution may be the public nuisance-special damage action. See generally PROSSER §89, at 611-14.

${ }_{28}$ PrOsser $\$ 89$, at 606 . In discussing the distinction between public and private nuisance, Prosser uses a water pollution situation as one of his textual examples: "Thus the pollution of a stream which merely inconveniences a number of riparian owners is a private nuisance only, but it may become a public one if it kills the fish." Id. at 606-07.

${ }^{20} \mathrm{Id}$. at 608.

so "The nuisance cases are virtually impossible to summarize or even categorize since they differ so greatly from state to state as to the reasonability of the defendant's conduct, the nature of the plaintiff's interest, and the interrelationship with other remedies, such as public nuisance." Rheingold, Civil Cause of Action for Lung Damage Due to Pollution of Urban Atmosphere, 33 Brooksyn L. REv. 17, 25 (1966). 
another difficult obstacle to overcome. If the pollution has been continuing for some time, the polluter's wrongdoing may have ripened into a judicially protected right through the application of that magical concept of property law-prescriptive rights-which with its twin-adverse possession-rewards wrongdoers who are patient, persistent, and non-reforming. In Hulbert, for example, even though the court was willing to go farther than most courts and enjoin a plant from operating as long as it polluted the air, it also held that the petitioner could not complain about the operation of one of defendant's other plants because the statute of limitations had run and defendant had thereby obtained a prescriptive right as to the operation of that plant. ${ }^{31}$

\footnotetext{
sI "[T] he defendant had acquired a prescriptive right to manufacture the maximum quantity of cement produced annually by that factory." 161 Cal. at 244, 118 P. at 980 . That a prescriptive right to maintain a private nuisance of air pollution may be obtained was early recognized by the English courts in Crump v. Lambert, [1867] L.R. 3 Eq. 409, 413, and has been followed by both federal and state courts in the United States. E.g., Dangelo v. McLean Fire Brick Co., 287 F. 14 (6th Cir. 1923); Herrlich v. New York Cent. \& H.R.R., 70 Misc. 115, 126 N.Y.S. 811 (Sup. Ct. 1910); see H. Wood, The LAW of Nuisances $\S \S 712.20$ (2d ed. 1883). However, many courts that have been presented with the problem have declined to recognize a prescriptive right because of the defendant's failure to meet the necessary burden of proof. E.g., Ralston v. United Verde Cooper Co., 37 F.2d 180 (D. Ariz. 1929), aff'd, 46 F.2d 1 (9th Cir. 1931); Campbell v. Seaman, 63 N.Y. 568 (1876); Bradbury Marble Co. v. Laclede Gas Light Co., 128 Mo. App. 96, 106 S.W. 594 (1907).

In Stamm v. City of Albuquerque, 10 N.M. 491, 503, 62 P. 973, 974 (1900), the court said: "Theoretically, the right may be ... acquired, but practically there are very few cases in which it can be established." Accord, H. Wood, supra at \$712. Thus one claiming such a right assumes the burden of showing that for the full period of the statute of limitations he has asserted and exercised the right to violate the law to the extent and with the results charged and proved against him, with the practical acquiescence of the person injured, and to the extent that during the whole time an action would lie against him. Id. $\$ \S 713,715-16,718$.

Much of the confusion in the area stems from the analytical problem of identifying the analogous grant of an easement to which this prescriptive right may be compared. The problem in such an analysis arises from the fact that the polluter is committing an act on his own land, rather than fulfilling the formal requirements of an easement by entering the victim's land. Dangelo v. McLean Fire Brick Co., supra, a case which upheld the ability to maintain such a prescriptive right, dismissed the problem by finding entry in the deposit of substances on the plaintiff's land by the defendant. The court drew an analogy to the field of water pollution and prescriptive user.

Because air pollution has historically been the basis of nuisance actions, the courts have developed an intermediate theory which is far more analogous to prescriptive user than to adverse possession, and have avoided dealing with the problems that would arise from an analysis of the ownership of the air. Other problems that have contributed to an already befogged-or smogged as the case may be-area, however, are the application of the theories of laches and of judicial grace in balancing equities in actions seeking equitable relief. See, e.g., Hulbert v. California Portland Cement Co., 161 Cal. 239, 118 P. 928 (1911); Richards' Appeal, 57 Pa. 105 (1868); Madison v. Ducktown Sulphur, Copper \& Iron Co., 113 Tenn. 331, 83 S.W. 658 (1904).
} 
Another concept of the law of nuisance which may strike down the would-be private controller of air pollution is the doctrine commonly referred to as "coming to the nuisance." In Waschak $v$. Moffat, ${ }^{32}$ for example, although the Supreme Court of Pennsylvania reversed a judgment for damages, primarily on other grounds, which the jury found plaintiffs to have sustained from defendant's emission of pollutants, the court, quoting Justice Musinanno in an earlier lower court decision, stated:

"The plaintiffs are subject to an annoyance. This we accept, but it is an annoyance they have freely assumed. Because they desired and needed a residential proximity to their places of employment, they chose to found their abode here. It is not for them to repine; and it is probable that upon reflection they will, in spite of the annoyance which they suffer, still conclude that, after all, one's bread is more important than landscape or clear skies.

Without smoke, Pittsburgh would have remained a very pretty village.'38

Although Waschak is not in accordance with the prevailing rule as to "coming to the nuisance," the doctrine is still likely to plague the complainer of pollution, if not in estoppel teruns, as a matter to be considered in "balancing the equities." 34

Since it is well established that no prescriptive right may be obtained in reference to a public nuisance, Fertilizing Co. v. Hyde Park, 97 U.S. 659 (1878); Dolata v. Berthelet Fuel \& Supply Co., 254 Wis. 194, 36 N.W.2d 97 (1949), the trend toward dealing with air pollution both legislatively and judicially as a public rather than private nuisance problem has decreased the availability of prescriptive right as a defense for air polluters. As there is less and less room for the prescriptive polluter to operate, and as police regulation becomes more widespread, the concept of a prescriptive right to pollute the air may soon only be remembered as an historical example of judicial legerdemain.

$82379 \mathrm{~Pa} .441,109$ A.2d 310 (1954).

ss Id. at 452,109 A.2d at 316 (emphasis in original). It is interesting to note that Justice Musmanno, a supreme court justice at the time of the instant case, dissented from the majority opinion. Id. at 455,109 A.2d at 318 .

s. "The question frequently arises, whether the plaintiff assumes the risk and is barred from recovery by the fact that he has 'come to the nuisance' by purchasing land and moving in next to it after it is already in existence or operation. The prevailing rule is that in the absence of a prescriptive right the defendant cannot condemn the surrounding premises to endure the nuisance, and that the purchaser is entitled to the reasonable use and enjoyment of his land to the same extent as any other owner, so long as he buys in good faith and not for the sole purpose of a vexatious lawsuit. This is true in particular, for obvious reasons, of public nuisances, and of those private ones which the defendant could abate at any reasonable cost. There are cases, however, which have held that the plaintiff is barred by his voluntary choice of a place to live, particularly where the defendant's activity is one in which the public has a 
Trespass

The complainer of air pollution who cannot or may not be able to push a nuisance action past the balance of equities, public vs. private, prescription, and "coming to the nuisance" hurdles may need to or wish to ground his cause of action on a theory other than nuisance. Trespass in many instances is a suitable alternative.

In addition to the possibility of avoiding the difficulties discussed above, there are two other distinct advantages to proceeding on a theory of trespass rather than nuisance. First, there are burden and necessity of proof differences since, at least in theory, no damage need be shown for a plaintiff to prevail in a trespass action while in nuisance actual damages must be proved. Secondly, and usually more importantly, statutes of limitations are generally considerably shorter for nuisance actions than for trespass.

Most of the important aspects of pollution control where trespass is used as the theory of the action can be seen by looking at the litigation which has resulted from the air pollution caused by one aluminum plant-the Reynolds Aluminum plant at Troutdale, Oregon. There are three cases to examine: (1) Arvidson $v$. Reynolds Metals Company, ${ }^{35}$ decided by the Federal District Court for the Western District of Washington in 1954, (2) Fairview Farms, Incorporated $v$. Reynolds Metals Company, ${ }^{36}$ which was decided on July 9,1959 , by the Federal District Court for Oregon, and (3) Martin v. Reynolds Metals Company, ${ }^{37}$ decided by the Supreme Court of Oregon on July 29, 1959.

In Arvidson the plaintiffs, who operated farms in Washington, sought damages and injunctive relief against defendant because of alleged damage to lands and cattle claimed to have been caused by fluorides discharged from defendant's Troutdale plant. The court noted that aluminum is produced in a manner that unavoidably causes fluorides to be discharged into the atmosphere from the plant stacks, and that these fluorides eventually may be deposited on

major interest; and the safer and more accurate statement would appear to be that 'coming to the nuisance' is merely one factor, although clearly not the most important one, to be weighed in the scale along with the other elements which bear upon the question of 'reasonable use." Prosser $\$ 92$, at 632.

${ }_{85} 125$ F. Supp. 481 (W.D. Wash. 1954), aff'd, 236 F.2d 224 (9th Cir. 1956), cert. denied, 352 U.S. 968 (1957).

38 176 F. Supp. 178 (D. Ore. 1959).

87221 Ore. 86, 342 P.2d 790 (1959), cert. denied, 362 U.S. 918 (1960). 
lands within a ten-mile radius of the plant. ${ }^{38}$ In addition, it recognized that "[f]luorides of some of the types escaping from the plants, if ingested in excessive quantities, are capable of causing damage to cattle."3o

Nevertheless, the court found for defendants, and in so doing gave a rather mild "balance the equities" argument:

Whether the measures taken by defendant to minimize the escape of fluorides from its plants are the maximum possible consistent with practical operating requirements is yet to be determined, but apparently American industry has not yet developed anything better. The record shows that the United States has a very important interest in the continued operation of these plants for their large scale production of aluminum essential to national defense. ${ }^{40}$

In reference to plaintiffs' theory of action, the court commented:

In the complaints and pretrial orders plaintiffs grounded the actions in trespass, as distinguished from trespass on the case, and later asserted nuisance as an alternative basis of Jiability. ${ }^{41}$

Implicit in this court's limitation decision was determination of the legal basis of the actions as being trespass on the case under Washington law. ... A review of the Washington cases ... leaves this court in no doubt but that the Washington Supreme Court regards claims of the nature of those presented in these cases as being based on common law trespass on the case as distinguished from trespass quare clausum fregit. ...

The Washington court holds that when the injury complained of is the immediate and direct result of defendant's acts or omissions, the action is for trespass whereas when the injury is consequential, the action is on the case. ... The distinction drawn by the Washington court between immediate and consequential injury is based on the character of the acts or omissions causing the injury and on whether the injury results immediately upon the occurrence of the act or omission. In the present cases the injury to plaintiffs, if any, was of a nonintentional character occurring a considerable time following the failure of [sic] inability of defendant to completely eliminate the effluence of fluorides from its plants; accordingly, the injury was consequential rather than im-

\footnotetext{
${ }^{38} 125$ F. Supp. at $482-83$.

so Id. at 483 .

$10 \mathrm{Id}$.

${ }^{41}$ Id. at 486.
} 
mediate and direct as those terms are interpreted by the Washington court in the law of trespass. ${ }^{12}$

In Fairview Farms the plaintiff, which conducted a dairy farming operation in Oregon near Reynolds' Troutdale plant, ${ }^{43}$ filed an action in trespass and also sought a permanent injunction against Reynolds, alleging that its dairy cows had been injured by fluorides which had entered its lands from Reynolds' plant, and that the fume control system in that plant was not efficient. Reynolds denied plaintiff's contentions pleading de minimis, and in the alternative pleaded that the action lie in nuisance. ${ }^{44}$

The court rejected both the de minimis and nuisance-ratherthan-trespass arguments:

A few cases hold directly contra to the holding of this Court, but a reading of those cases leaves this Court with the impression that the foreign jurisdiction was looking past the initial question of whether there was in fact a trespass and was concerned with balancing the equities to determine the existence or nonexistence of a trespass. That line of cases this Court rejects, and holds that air-borne liquids and solids deposited upon the Fairview lands constituted a trespass. As early as 1911 the Oregon Court recognized our changing society ....

One of these changes is scientific development which today allows the court, with the aid of scientific detecting methods, to determine the existence of a physical entry of tangible matter, which in turn gives rise to a cause of action in trespass under the Oregon Court's holding that every unauthorized entry upon land of another constitutes actionable trespass. ${ }^{45}$

The court held that the statute of limitations as to trespass applied and therefore allowed damages for a six-year period. Injunctive relief was denied, however, on the theory that the pollution was not reasonably certain to be repeated and that the defendant had apparently done all it could to control the pollution.

The plaintiffs in Martin, also Oregon cattle raisers near the

12 Id. at $487-88$.

18 There was a long history of previous transactions between Reynolds and Fairview concerning the deposit of fluorides on Fairview's farms. Reynolds had continuously informed Fairview of areas of excessive fluoride deposits where cattle should not be grazed and had paid Fairview feed costs from 1947 to 1951. 176 F. Supp. at 183.

"Id. at 184. The court stated that a trespass action in Oregon carried a six-year statute of limitations, ORE. REv. STAT. $\$ 12.080$ (Supp. 1965), while a nontrespassory action carried a two-year limitation. Id.

$18 \mathrm{Id}$. at 186. 
Troutdale plant, alleged that their cattle were poisoned by ingesting the fluorides which escaped from defendant's alumium plant and contaminated the forage and water on their land. On appeal from a verdict for plaintiffs below, the defendant's principal assignment of error was its contention that the trial court was mistaken in identifying the defendant's invasion of the plaintiffs' land as a trespass.

According to the court, the "gist" of the defendant's argument was that "a trespass arises only when there has been "breaking and entering upon real property,' constituting a direct, as distinguished from a consequential invasion of the possessor's interest in land," and that the mere settling of fluoride deposits upon the plaintiffs' land was not sufficient to meet these requirements. ${ }^{47}$ The court, however, was not persuaded:

The view recognizing a trespassory invasion where there is no "thing" which can be seen with the naked eye undoubtedly runs counter to the definition of trespass expressed in some quarters.... It is quite possible that in an earlier day when science had not yet peered into the molecular and atomic world of small particles, the courts could not fit an invasion through unseen physical instrumentalities into the requirement that a trespass can result only from a direct invasion. But in this atomic age even the uneducated know the great and awful force contained in the atom and what it can do to a man's property if it is released. In fact, the now famous equation $E=m c^{2}$ has taught us that mass and energy are equivalents and that our concept of "things" must be reframed. If these observations on science in relation to the law of trespass should appear theoretical and unreal in the abstract, they become very practical and real to the possessor of land when the unseen force cracks the foundation of his house. The force is just as real if it is chemical in nature and must be awakened by the intervention of another agency before it does harm.

If, then, we must look to the character of the instrumentality which is used in making an intrusion upon another's land we prefer to emphasize the object's energy or force rather than its size. Viewed in this way we may define trespass as any intrusion which invades the possessor's protected interest in exclusive possession, whether that intrusion is by visible or invisible pieces of matter

221 Ore. at 89,342 P.2d at 791 .

"Id. 
or by energy which can be measured only by the mathematical language of the physicist.

We are of the opinion, therefore, that the intrusion of the fluoride particulates in the present case constituted a trespass. ${ }^{48}$

While Martin and Fairview foretell greater success for private pollution controllers who ground their causes in trespass rather than in nuisance, they nevertheless face the problem of the trespass having occurred over a period of time so that a prescriptive right may have accrued. If so, the only hope for the would-be pollution controller would seem to be to fall back on the idea that the pollution constituted a public nuisance against which no prescriptive right may ripen and then attempt to prove special damages.

\section{Negligence}

A third legal basis for private control of air pollution that causes injury to property or person is through an action for damages based on negligence. ${ }^{49}$ For example, in the case of Greyhound Corpora-

is Id. at 93-94, 342 P.2d at 793-94.

"One reason a plaintiff may wish to proceed on a negligence theory is the greater likelihood of obtaining punitive damages than if he phrased his cause in trespass or nuisance. It is difficult, however, to present a prevailing judicial consensus as to the availability of punitive damages under any of these possible theories of recovery. To say that the majority of jurisdictions allow the awarding of such damages would be misleading, since within this majority there is no common view as to the theory upon which the allowance of such damages is based. Moreover, four states reject punitive damages entirely: Louisiana, Moore v. Blanchard, 216 La. 253, 43 So. 2d 599 (1949); Massachusetts, City of Lowell v. Massachusetts Bonding \& Ins. Co., 313 Mass. 257, 47 N.E.2d 1021 (1943); Nebraska, Wilfong v. Omaha \& C.B. St. Ry., 129 Neb. 600, 262 N.W. 537 (1935); and Washington, Anderson v. Dalton, 40 Wash. 2d 894, 246 P.2d 853 (1952). Two states, Michigan and New Hampshire, allow such damages but regard them as extra compensation for injured feelings or sense of outrage rather than pun. ishment. Wise v. Daniel, 221 Mich. 229, 190 N.W. 746 (1922); Bruton v. Leavitt Stores Corp., 87 N.H. 304, 179 A. 185 (1935). Connecticut, on the other hand, limits punitive damages to the expenses of litigation less taxable costs. Tedesco v. Maryland Cas. Co., 127 Conn. 533, 18 A.2d 357 (1941). The traditional view has been that punitive damages are to be awarded when there is present an element of oppression, malice, fraudulent or evil motive, or such a conscious and deliberate disregard of the interests of others that the conduct may be called wilful and wanton. See, e.g., Knierim v. Izzo, 22 Ill. 2d 73, 174 N.E.2d 157 (1961); Swinton v. Savoy Realty Co., 233 N.C. 723, 73 S.E.2d 785 (1953).

Two theories of punitive damages will be mentioned in this note. The first, in connection with the Reynolds cases, is the Oregon position; and the second is the Indiana principle, which is based on the double jeopardy doctrine.

In Reynolds Metals Co. v. Lampert, 316 F.2d 272 (9th Cir. 1963), the court of appeals reversed and remanded the case for consideration of various issues of damages saying: "The District Court erred in withdrawing appellees' claim for punitive damages from the consideration of the jury. Where there is evidence that the injury was done maliciously or wilfully and wantonly or committed with bad motive or recklessly 
tion $v$. Blakley, ${ }^{50}$ the plaintiff was allowed substantial recovery in a negligence action for the brain and nerve damage she allegedly suffered from breathing air containing a substantial amount of carbon monoxide while a passenger on defendant's bus.

Of course, the gravamen of an action for damages based on negligence is a showing by the plaintiff of defendant's negligence and a causal relation between the negligence and plaintiff's injury. This is not a particularly onerous task when a deadly pollutant such as carbon monoxide is involved in air admittedly under defendant's exclusive control-as in Blakley. However, where one brings an action for lung damage against a local cement plant, for example, the case gets extremely difficult from a causation standpoint. ${ }^{51}$

so as to imply a disregard of social obligations, punitive damages are justified. Fisher v. Carlin, 219 Ore. 159, 346 P.2d 641.

"Here the record discloses that appellants had known for several years that fluorides from their plant were settling on appellees' land, with resultant damage to appellees' crops. It thus could have been found that their trespass was done knowingly and wilfully, that it was intentional and in wanton disregard of appellants' social obligations.

"To justify an award of punitive damages, it is not necessary that the act have been done maliciously or with bad motive. Where it has become apparent, as it has here, that compensatory damages alone, while they might compensate the injured party, will not deter the actor from committing similar trespasses in the future, there is ample justification for an award of punitive damages." Id. at 275 (emphasis added). On rehearing, 324 F.2d 465 (9th Cir. 1963), the court upheld the award of punitive damages made by the jury as permissible under Oregon law.

It is noted that while this case applied state law pursuant to the diversity rules of Erie R.R. v. Tompkins, 304 U.S. 64 (1938), the extension of the punitive damages doctrine to an area in which deterrence is the motivating factor for allowing the award was purely judicial in nature. If the application of the Reynolds' cases, as far as grounding civil actions for air pollution in trespass and nuisance, is comparable, then the possibility of an extension of the punitive damages doctrine in federal cases grounded in trespass or nuisance as a preventive measure against polluters is a distinct possibility.

Indiana's position on punitive damages is based on a state supreme court decision handed down in 1854-Taber v. Hutson, 5 Ind, 322 (1854). Pursuant to the principles delineated in that case, there can be no recovery of punitive damages if the civil tort is also a crime. Indiana is only one of three states which maintain such a doctrine, the others being Colorado, Murphy v. Hobbs, 7 Colo. 541 (1884), and Georgia, Cherry v. McCall, $23 \mathrm{Ga}$. 193 (1857). Aldridge, in The Indiana Doctrine of Exemplary Damages and Double Jeopardy, 20 IND. L.J. 123 (1945), analyzes the position as being based upon the theory that such an award would he unconstitutional under the double jeopardy clause of the state constitution and the federal constitution. Its special application to air and water pollution suits instituted by private individuals will depend upon the construction of the applicable statutes by the courts to determine whether the statutory penalties are criminal in nature so as to deny any recovery of punitive damages by a plaintiff in a civil action.

${ }^{80} 262$ F.2d 401 (9th Cir. 1958).

02 Rheingold asserts that the victim of urban air pollution can recover by joining the major polluters in the area. Rheingold, Civil Cause of Action for Lung Damage 
The typical air pollution oriented causation problems can be seen in Hagy v. Allied Chemical of Dye Corporation. ${ }^{52}$ Mrs. Hagy sought recovery for damages suffered to her larynx when she and her husband drove through smog which she alleged to have contained injurious sulfuric acid compounds negligently emitted from defendant's plant under inversion conditions. ${ }^{53}$ As the court stated:

[T] he theory of plaintiffs' case is (1) that Mrs. Hagy had a cancer of the larynx before her exposure to the smog but it had not been diagnosed as such, and her condition was such that she did not know it; (2) that her exposure to the smog and the irritation therefrom "lighted up" the dormant cancer; (3) that immediately following the exposure she lost her voice; (4) that her doctors then pressed their examinations, ruled out tuberculosis, took a biopsy of the larynx, and determined therefrom that she had a cancer of the larynx; (5) that a complete laryngectomy was then performed; and (6) that such operation might have been averted had she not been exposed to the smog and irritation therefrom. ${ }^{54}$

The defendant did not challenge the "take your victim as you find him" concepts of section 461 of the Restatement (Second) of Torts ${ }^{56}$ relied upon by plaintiffs, but based its appeal upon the

Due to Pollution of Urban Atmosphere, 33 BrookLyN L. REv. 17, 18, 27 (1966). None of the cases cited, however, support this contention. In fact, the only negligence case cited in the discussion is Hagy v. Allied Chem. \& Dye Corp., 122 Cal. App. 2d 361, 265 P.2d 86 (1954). Rheingold's proposition nevertheless seems to be sound. As long as sufficient testimony can be presented on causation to get to and persuade the jury, there is no reason why simple joint tortfeasor principles should not be applicd and recovery allowed accordingly. In this connection, Rheingold states without citing authority: "It is believed that generally it would be necessary to join no more than three parties in order to have under suit the agencies contributing the majority of the pollutants in the air." Rheingold, supra at 28.

${ }^{82} 122$ Cal. App. 2d 361, 265 P.2d 86 (1954).

83 " $[\mathrm{A}] \mathrm{n}$ inversion is a condition in which, instead of being warm near the ground and cold at a higher altitude, the air is cold near the ground and warm at a higher altitude. Since the cold air cannot and does not rise, as warm air would, the impurities which find themselves in the atmosphere are not carried away and a so-called smog results. Moreover, when there is a descending motion in the atmosphere . . the impurities are actually brought down to ground level." Id. at 363,265 P.2d at 88 . ot Id. at 367, 265 P.2d at 90 (emphasis in original).

E5 RestaTEMENT (SECOND) OF TORTS $\$ 461$ (1965) states: "Harm Increased In Extent By . Other's Unforeseeable Physical Condition.

"The negligent actor is subject to liability for harm to another although a physical condition of the other which is neither known nor should be known to the actor makes the injury greater than that which the actor as a reasonable man should have foreseen as a probable result of this conduct.

…

"Comment:

a. The rule stated in this Section applies not only where the peculiar physical condition which makes the other's injuries greater than the actor expected is not known 
assertion that as a matter of law the evidence was insufficient to permit the jury to find a causal connection between the smog and Mrs. Hagy's condition. The court affirmed the verdict below on the ground that:

The burden did not rest upon respondents to prove that the removal of respondent's larynx would not have been necessary but for her exposure to the smog; the burden was rather upon appellants to convince the jury that the operation would have been ultimately necessary in any event, even though the cancerous larynx had not been traumatized by the irritation of the smog. ${ }^{58}$

The defendant in Hagy admitted negligence. ${ }^{57}$ Absent such an admission or unless some strict liability principle can be applied, ${ }^{58}$ it would not be worthwhile to show a causal relationship between plaintiff's injury and defendant's act unless it can also be shown that the defendant was acting negligently. Once again, litigation over pollution by Reynolds' Troutdale plant is informative. In Martin v. Reynolds Metals Company, ${ }^{59}$ members of the Martin family brought actions for personal injuries which they allegedly suffered from the fluorine compounds escaping from defendant's plant. They presented witnesses as to the escape of toxic substances. The defendant, however, moved for a nonsuit. The court denied the motion, saying:

to him, but also where the actor could not have discovered it by the exercise of reasonable care, or, indeed even where it is unknown to the person suffering it or to anyone else until after the harm is sustained. A neghigent actor must bear the risk that his liability will be increased by reason of the actual physical condition of the other towards whom his act is negligent.

"Illustrations:

1. Through the motorman's negligent management of the A Company's trolley car the control lever strikes the breast of $B$, a passenger. The injury is apparently slight, but it causes a cancerous tendency to 'light up' and localize itself in the injured point, requiring the amputation of B's breast. $A$ is answerable for the harm caused by the cancer and the amputation."

Bo 122 Cal. App. 2d at 370, 265 P.2d at 92.

s7 "Appellants do not contend that there is insufficient evidence of negligence in the operation of their plant on that evening. At the opening of the discussion they say: "For the purpose of argument, we may assume that Allied should have discovered the inversion and stopped operating sooner than it did and that accordingly it did not act as a reasonably prudent producer of sulphuric acid would have acted under the circumstances." Id. at 364,265 P.2d at 88.

s Where inherently dangerous gases are the pollutants, the plaintif might argue ultrahazardous activity and seek the penumbra of Rylands v. Fletcher, L.R. 3 H.L. 330 (1868). See notes 70-86 infra and accompanying text.

89135 F. Supp. 379 (D. Ore. 1952), aff'd sub nom. Reynolds Metals Co. v. Yturbide, 258 F.2d 321 (9th Cir.), cert. denied, 358 U.S. 840 (1958). 
When the plaintiff proved the emanation of fluorine compounds from the plant of the defendant and the injury suffered by him as a result thereof, he made out a prima-facie case of negligence on the part of the defendant. So far as I am able to ascertain from the record no attempt has been made by the defendant to prove the cause of the emanation or the escaping of the fluorine componds so it is a question for the jury with all the evidence before it whether a preponderance of such evidence is in favor of the plaintiff.60

The Court of Appeals for the Ninth Circuit affirmed. ${ }^{01}$ This court first commented that there was sufficient evidence of causation between plaintiffs' injuries and the fluorides escaping from defendant's plant to support a jury verdict to that effect. In respect to the second point of the case, the submission to the jury of the question of negligence on the basis of res ipsa loquitor, the defendant argued strongly that it did all that was reasonable to prevent the escape of fluorides. The court, however, stressed the superior knowledge of defendant and the duty such knowledge places on a defendant under section 289 of the Restatement (Second) of Torts, $^{62}$ and testimony that the customary operation of an aluminum plant would not ordinarily cause damage to persons in the vicinity, and held that these two considerations made the case a proper one for the application of the doctrine of res ispa loquitor. ${ }^{\mathrm{C3}}$

Unfortunately, however, Yturbide [Martin below] leaves the basic "standard of care" question unanswered. Has a polluter met the standard of care required if ne shows, for example, that he puts out fewer pollutants than any other operation of his type or that he uses all available pollution control devices? Maybe there is no other way to produce aluminum-or what seems to impress courts just as much-no other economical way. All of which puts the

${ }^{\circ 0} I d$. at 382.

o1 Reynolds Metals Co. v. Yturbide, 258 F.2d 321 (9th Cir. 1958).

${ }^{62}$ Restatement (SECOND) OF TORTS $\$ 289$ (1965) states:

"Recognizing Existence of Risk

The actor is required to recognize that his conduct involves a risk of causing an invasion of another's interest if a reasonable man would do so while exercising (a) such attention, perception of the circumstances, memory, knowledge of other pertinent matters, intelligence, and judgment as a reasonable man would have; and (b) such superior attention, perception, memory, knowledge, intelligence, and judgment as the actor himself has."

${ }^{\circ 3}$ It is interesting to note that the court of appeals in a previous unreported de. cision on the same case thought the case proper for the application of Rylands $v$. Fletcher concepts. $258 \mathrm{~F} .2 \mathrm{~d}$ at 326. 
court and/or jury in the position of having to grapple with a political, even philosophical, question-should the manufacturer be considered negligent if he does not use all pollution control devices available, even if his profit margin will be reduced or even eliminated by so doing.

The standard to which the courts will hold the producer of pollutants depends in final analysis upon the view the judge and jury take of the social utility of pollution control, which is in turn a product of how serious a danger to our society they consider air pollution. The standard no doubt will be seriously affected not only by the state of scientific knowledge as to the causes and effects of air pollution, but also by the state of technology and the extent to which present pollution control devices are effective and economically feasible.

The recent case of Renken $v$. Harvey Aluminum, Incorporated, ${ }^{64}$ although trespass rather than negligence oriented, indicates the approach to "standard of care" the courts should take and which they no doubt will take when the importance of air pollution is impressed upon them.

After hearing expert witnesses, the Renken court concluded that the installation of cell hoods and electrostatic precipitators would greatly reduce, if not entirely eliminate, the escape of the harmful fluorides being emitted from the defendant's aluminum plant, ${ }^{65}$ and required the defendant to install such devices within one year or be enjoined from further air polluting operations. ${ }^{60}$ The court reasoned:

While the cost of the installations of these additional controls will be a substantial sum, the fact remains that effective controls must be exercised over the escape of these noxious fumes. Such expenditures would not be so great as to substantially deprive defendant of the use of its property. While we are not dealing with the public as such, we must recognize that air pollution is one of the great problems now facing the American public. If necessary, the cost of installing adequate controls must be passed on to the ultimate consumer. The heavy cost of corrective devices is no reason why plaintiffs should stand by and suffer substantial damage. ${ }^{87}$

\footnotetext{
226 F. Supp. 169 (D. Ore. 1963).

${ }^{85} \mathrm{Id}$. at 172.

os Id. at 176 .

${ }^{67}$ Id. at 172 (emphasis added).
} 
$[\mathrm{O}]$ nce the plaintiffs established that fluorides were deposited on their lands from the plant of the defendant, the burden of going forward with the evidence was on the defendant to show that the use of its property, which caused the injury, was unavoidable or that it could not be prevented except by the expenditure of such vast sums of money as would substantially deprive it of the use of its property. ${ }^{68}$

There is no room for application of the doctrine of balancing of the equities at this time. The required improvements should entirely eliminate the problem. ${ }^{6 \theta}$

Renken properly suggests that the standard required of those who produce pollutants is that they use all available pollution control devices regardless of their cost so long as the expense does not substantially deprive defendants of the use of their property. The question that even Renken leaves unanswered, however, is what approach the court should take in setting the required standard of conduct or deciding to grant an injunction when the defendant uses all presently available pollution control devices, but refuses either alone or in conjunction with the rest of the industry to conduct or share the cost of research to develop more efficient methods of pollution control. While public pollution control is doubtless the best avenue for assuring the development of as effective pollution control devices as the existing state of technology will support, there would seem to be no reason why a court confronted with a negligence action should not consider the defendant's activities in developing better control devices as one of the elements in judging the reasonableness of his conduct. Similarly, it would seem that a court confronted with a nuisance or trespass action should take this same matter into consideration as part of the balancing of equities in deciding whether or not an injunction will issue.

\section{Strict LiabiLity}

Although strict liability concepts do not necessarily give rise to a separate "cause of action,"70 they may be and often are used by complainers of air pollution. In the broadest sense of the term both

${ }^{\circ 8}$ Id. at 174 .

oo Id. at 176. The court comments in reference to the Fairview Farms case that: "The basic reason the Court did not grant an injunction in the Fairview case was that there was no evidence the acts or conduct of Reynolds were reasonably certain to be repeated in the future." Id. at 173.

${ }^{70}$ See note 7 supra. 
trespass $^{71}$ and nuisance ${ }^{72}$ are strict liability oriented since recovery may be had without a showing of fault. In the air pollution field, however, individuals often suffer personal injury or property damage from emissions of poisonous gases which result from activities that cannot be easily labeled a nuisance or with respect to which the courts may fail to find the invasion necessary for trespass. In such cases the complainer of the pollution often needs to urge strict liability concepts separate from nuisance and trespass principles. The Supreme Court of Pennsylvania in Waschak v. Moffat Coal Company ${ }^{73}$ distinguished three theories for allowing recovery against one from whose property material has escaped without negligence or fault and caused damage to another. The court stated:

From the multitude of cases there appear to have been promulgated three rules of law where there has been an invasion of interests in the private use of land. They arise most frequently where, without negligence or fault, material escapes to land of another causing damage. The rules may be thus stated:

(1) The English rule of Rylands v. Fletcher, L.R. 3 H.L. 330

(a leading case which is frequently cited)

(2) Absolute Nuisance Doctrine

(3) Restatement Rules. ${ }^{74}$

${ }^{71}$ PROSSER $\S 13$. Prosser, however, points out that this concept has been repudiated in England and is losing favor in the United States. Id.

II In the nuisance field, the concept of liability without fault has gained wide acceptance because of the prevailing theory that if a nuisance exists there is no necessity to prove negligence on the part of the defendant. See, e.g., E. Rauh \& Sons Fertilzer Co. v. Shreffer, 139 F.2d 38 (6th Cir. 1943). This is based on the assertion that the creation of the nuisance is, in itself, the intentional act upon which liability is based. Id. But see Arvidson v. Reynolds Metals Co., 125 F. Supp. 481 (W.D. Wash. 1954), aff'd, 236 F.2d 224 (9th Cir. 1956), cert. denied, 352 U.S. 968 (1957) (reasonableness test applied). The primary problem involved in the nuisance raea is proving an actionable nuisance to the court. See Waschak v. Moffat Coal Co., 379 Pa. 441, 109 A.2d 310 (1954). Whether there is an actionable nuisance depends on the surrounding circumstances of the case, such as the nature and reasonableness of the defendant's use of his property, Arvidson v. Reynolds Metals Co., supra at 488, the extent of the injury, see, e.g., DeBlois v. Bowers, 44 F.2d 621, 623 (D. Mass. 1930), the location of the propexty, see, e.g., Kelley v. National Lead Co., 240 Mo. App. 47, 60, 210 S.W.2d 728, 735 (1948), and the probable effect of the defendant's activities upon the surrounding environment, see, e.g., id. In other words, a balancing of the equities concept is frequently applied to determine the presence of an actionable nuisance, and absolute nuisance is a label which is very rarely applied. See, e.g., id.

78 379 Pa. 441, 109 A.2d 310 (1954).

"Id. at 445-46, 109 A.2d at 313. Absolute liability, that is, liability irrespective of negligence on the part of the defendant, may be rested upon any one or more of the following theories: (1) the theory of nuisance, often called "absolute nuisance," see notes 8-34 supra and accompanying text; (2) the theory, closely connected with the theory of nuisance, that every person should so use his own property as not to injure 
The court in Waschak adopted the Restatement rule and agreed that its adoption "will obviate the difficulty and confusion in attempting to reconcile or distinguish the great mass of cases." 75 Under section 822 of the Restatement of Torts:

The actor is liable in an action for damages for a non-trespassory invasion of another's interest in the private use and enjoyment of land if,

(a) The other has property rights and privileges in respect to the use or enjoyment interfered with; and

(b) the invasion is substantial; and

(c) the actor's conduct is a legal cause of the invasion; and

(d) the invasion is either

(i) intentional and unreasonable; or

(ii) unintentional and otherwise actionable under the rules governing liability for negligent, reckless or ultrahazardous conduct. ${ }^{76}$

Applying this rule, the court reversed a verdict for plaintiff who had sued for damages in trespass for injury to the paint on his house which the jury found to have been sustained by the emission of hydrogen sulfide gas from defendant's coal culm banks. ${ }^{77}$

The majority of the court reasoned that section 822 of the Restatement "encompasses the entire statement of principles of liability ...."78 Since defendant's conduct was neither intentional nor ultrahazardous, there could be no liability. The court left virtually undiscussed the ultrahazardous conduct aspect of the case except by seemingly equating it with "absolute nuisance" concepts.

The finding in Waschak that strict liability and absolute nuisance were co-extensive and that the nuisance must be shown to exist

that of another ("sic utere tuo ut alienum non laedas"), see, e.g., Morgan v. High Penn Oil Co., 238 N.C. 185, 193, 77 S.E.2d 682, 689 (1953); (3) the theory that one engaged in uitrahazardous activities is liable to another whose person or property is injured by such activities, although the utmost care is exercised to prevent harm, sce notes 81-86 infra and accompanying text; (4) the closely related doctrine of Rylands $v$. Fletcher, see notes 79.80 infra and accompanying text and note 58 supra; (5) the Restatement rule, which represents a combination of the theories mentioned above, see notes 82-83 infra and accompanying text; and (6) the theory of trespass, see notes 35 . 69 supra and accompanying text.

$75379 \mathrm{~Pa}$. at 449,109 A.2d at 314.

${ }^{76}$ Restatement OF TORTS $\$ 822$ (1939).

${ }^{77}$ The court ignored the trespass aspects of the case except for mentioning that it was an action in trespass, and analyzed the case solely in nuisance and strict liability terms.

${ }^{78} 379 \mathrm{~Pa}$. at $454,109 \mathrm{A.2d}$ at 317. 
by the plaintiff before the doctrine of strict liability will be applied would appear to be the prevailing view in those jurisdictions which have analyzed the question of liability without fault. Therefore, under the cover of "absolute nuisance" the Rylands v. Fletcher" concept of strict liability has gained acceptance in the majority of American jurisdictions. ${ }^{80}$

In actions which arise from personal injury to the plaintiff, the doctrine of ultrahazardous activity, as expounded in cases which have extended Rylands $v$. Fletcher, has been infrequently used with success in the air pollution field. It has been accepted in one case and rejected in another involving the emission of gases which resulted in injury to the plaintiff. Lutheringer $v$. Moore ${ }^{81}$ accepted the definition found in section 520 of the Restatement of Torts:82 "An activity is ultra-hazardous if it (a) necessarily involves a risk of serious harm to the person, land or chattels of others which cannot be eliminated by the exercise of utmost care, and (b) is not a matter of common usage." 83 In this case, damages were allowed, without proof of negligence on the part of the defendant, for injuries arising from the escape of hydrocyanic acid gas used by defendant in a fumigation process. The gas, however, was stated by statute to be a "dangerous or lethal chemical," and this was emphasized in the opinion. ${ }^{84}$

In a contrary case, Fritz v. E. I. duPont de Nemours \& Company, ${ }^{85}$ injuries were sustained by the plaintiff, an employee, from chlorine gas and fumes which escaped in a manner unknown to the defendant. The court found that the use of chlorine gas was not so unusual or hazardous that the defendant should have foreseen the risk of injury and have become liable as an insurer in case of injury. In other words, the court drastically narrowed the concept of ultrahazardous activities, stating that to so restrict a corporation in the use of dangerous substances would be non-utilitarian in nature, and therefore the plaintiff must prove: (1) either an actionable nuisance and thus avoid the problem of showing negligence, or (2) be pre-

\footnotetext{
${ }^{70}$ L.R. 3 H.L. 330 (1868).

so See PROSSER § 77.

s2 31 Cal. 2d 489, 190 P.2d 1 (1948).

82 RESTATEMENT OF TORTS $\$ 520$ (1938).

sa $31 \mathrm{Cal} .2 \mathrm{~d}$ at $498,190 \mathrm{P.2d}$ at 7 .

84 Id. at 497,190 P.2d at 6 .

8s 45 Del. 427,75 A.2d 256 (1950).
} 
pared to resort to the established theories of res ipsa loquitur and the special control of the defendant over the evidence.

The paucity of authority makes prediction difficult, but it would seem that the complainer of pollution will have formidable odds against recovery unless in addition to strict liability-ultrahazardous activity-he can talk nuisance, trespass, and perhaps res ipsa loquitur as well. ${ }^{88}$ Certainly the successful cases are likely to be so sparse as to have negligible pollution control consequences.

An extension of the concept of strict liability is found in the development of the statutory liability of employers under state and federal workmen's compensation acts. Since injuries to workers caused by air pollution may come within the purview of the acts, this is another cause of action on which one injured by air pollution may proceed. The trend of decisions appears to be toward abandoning the original "accident" orientation of the acts and toward extending their coverage to all areas of job-related disease. Although this will doubtless allow many injured by pollution to recover who could not do so on pure negligence, nuisance, and trespass theories, the pollution control consequences will again be slight. In fact, since some employees who would have a cause of action without such a statute may now find their statutory remedy exclusive, the polluter may find his pollution cheaper since at least part of his damage is paid for on an insurance principle and the risk of high jury verdicts is avoided. ${ }^{87}$

\footnotetext{
${ }^{86}$ Prosser concludes that the American decisions, like the English ones, have applied the principle of Rylands $v$. Fletcher, and its extension to ultrahazardous activities and absolute nuisance, only to things out of the ordinary-the abnormally dangerous condition or activity which is not a "natural use." Prosser \$77. Euclid v. Ambler Realty Co., 272 U.S. 365, 388 (1926), speaks of nuisance as "merely a right thing in the wrong place,-like a pig in the parlor instead of the barnyard."

${ }^{87}$ Although the statutes tend to be comprehensive in coverage, an area which may still present a field of continuing litigation concerns a type of job-related injury to which workmen's compensation may not extend. It is to be noted that most statutes cover accidents, a term which may not include within its scope diseases which may be cumulative in nature and which are caused by air pollution sources such as gaseous emissions in a plant. In such a case it is assumed that the worker would be left to his common law remedy. See Triff v. National Bronze \& Aluminum Foundry Co., 135 Ohio St. 191, 20 N.E.2d 232 (1939). If the statutes were extended by interpretation to cover attritional diseases, the statutory compensation would be the sole measure of relief and any common law remedy would be barred to the extent that the statute was applicable. Prosser $\$ 82$. Since the statutory remedy is exclusive, e.g., Cell v. Yale \& Towne Mfg. Co., 281 Mich. 564, 275 N.W. 250 (1937); delBusto v. E.I. Dupont de Nemours \& Co., 167 Misc. 920, 5 N.Y.S.2d 174 (Sup. Ct. 1938), aff'd per curiam, 259 App. Div. 1070, 21 N.Y.S.2d 417, appeal denied, 284 N.Y. 817,29 N.E.2d
} 


\section{Effect of Pollution Control Legislation}

With the rapid increase of statutes and ordinances relating to pollution control, the question has already arisen as to the effect of such legislation on private rights.

In the Renken case, ${ }^{88}$ the defendant contended that the Oregon air pollution control law preempted the field and foreclosed a private action. ${ }^{80}$ The court stated:

Defendant's contention that the Oregon Air Pollution Law pre-empts this field is without foundation. Specifically recognized by ORS 449.820 is the right by an individual to prosecute a suit to abate a private or public nuisance. The record in this case is sufficiently broad to be viewed as a suit to abate a nuisance, as well as a suit to enjoin a continuing trespass. For that matter, a continuing trespass could well be a nuisance. The York cases recognize that the deposit of smoke screenings and particulates on the lands of another amounts to a nuisance. The rule of construction 'expressio unius est exclusio alterius,' for which defendant contends, is not a rule of law, but is a mere guide in determining intent and such a rule must be harmonized with all other rules of construction. It is a rule which should be applied with caution and merely as an auxiliary rule to determine the legislative intention.

... Thus, it is seen, that the common ordinary definition of nuisance includes the continued or repeated invasion or disturbance of a right, such as a continuing trespass. Surely, the Oregon Legislature employed the word in that sense when enacting ORS 449.820. Furthermore, all statutes which encroach on personal or property rights of an individual are to be construed strictly, and in the absence of express words or necessary implication, it will be presumed that such statute is not intended to interfere with or prejudice a private right or title ....

975 (1940). However, there are also a number of cases holding that the statutory remedy is not exclusive where the injury or disease is not compensable under the act. E.g., Boal v. Electric Storage Battery Co., 98 F.2d 815 (3d Cir. 1938); Mapes v. Massey-Harris Co., 19 F. Supp. 667 (W.D.N.Y. 1937); Kane v. Federal Match Corp., 5 F. Supp. 507 (M.D. Pa. 1934). For a state case which overruled an earlier decision and allowed a suit at common law when the injury was uncompensated by the statute see Triff $\mathrm{v}$. National Bronze \& Aluminum Foundry Co., supra.

226 F. Supp. 169 (D. Ore. 1963).

So ORE. REV. STAT. $\$ 449.820$ (1965) provides, in part: "The provisions of this section shall not prevent the maintenance of actions or suits relating to private or public nuisances brought by any other person, or by the state on relation of any person without prior order of the Sanitary Engineer." 
We must assume that the Oregon Legislature was familiar with this rule of construction and that it never intended, by this legislation, to deprive individuals, such as plaintiffs, of their common law right to enjoin a flagrant violation of those rights nor to pursue their right to enjoin a continuing trespass in a proper Court. 80

Since no argument has been advanced that the assertion of private rights interferes with public control, it seems clearly desirable to preserve private rights on the passage of control statutes and ordinances. Given this conclusion the problem is really one of drafting legislation so as to preserve private rights. ${ }^{91}$

\section{CoNCLUSION}

What the would-be private pollution controller finds, whether he proceeds in nuisance, trespass, or damages for negligence, is that his claim of right to pollution-free air will be subjected, along with the polluter's claim of right, to a balancing of the equities in which the court will attempt to measure benefits and costs to each, and, hopefully, to society as well. The plaintiff's success depends upon how much importance those who make, apply, and interpret the law attach to control of pollution as well as the technological capability and cost of controlling it.

${ }^{00} 226 \mathrm{~F}$. Supp. at 175-76. In certain areas of federal legislation, the statutory remedy is expressly exclusive in nature. See Federal Tort Claims Act $\$ 423,28$ U.S.C. $\$ 2679$ (1964). Whether federal legislation extends to concepts of strict liability is still open to question. In Dalehite v. United States, 346 U.S. 15, 44 (1952) (emphasis added), it was stated that the Federal Tort Claims Act "is to be invoked only on a 'negligent or wrongful act or omission' of an employee." But the court in Wildwood Mink Ranch v. United States, 218 F. Supp. 67, 69 (D. Minn. 1963), stated that the correct interpretation of the earlier holding was "that the mere fact that absolute liability under State law may be imposed against individuals for certain dangerous activities does not relieve the Government from liability under the Tort Claims Act where the misfeasance thereby required is established." The court found that the negligent actions of Navy pilots in flying too low over the plaintiff's mink ranch rendered the United States answerable in damages for the unforeseen consequences caused by the noise to the plaintiff's minks, citing Gallick v. Baltimore \& O.R.R., 372 U.S. 108 (1963). The consequences of such a decision under $\$ 410$ (a) of the Federal Tort Claims Act, 28 U.S.C. \$2674 (1964), which makes the United States liable under the local law of the place where the tort occurs for the negligent or wrongful acts or omissions of federal employees within the scope of their employment, "in the same manner and to the same extent as a private individual under like circumstances," has yet to be tested as far as an extension from "noise" pollution to other types of polIution.

${ }^{91}$ A statement in the act or ordinance that none of its provisions is intended to diminish any private rights of control or recovery existing prior to its passage would seem desirable. 
As Martin, ${ }^{92}$ Fairview, ${ }^{93}$ and Renken ${ }^{94}$ indicate, once the necessity of air pollution control, even at large cost, is ingrained in those who apply the law, so-called equities will be balanced in favor of the plaintiff seeking to assert his right to nonpolluted air, or to recover the damages he suffers from polluted air. It is submitted, therefore, that our legal concepts of nuisance, trespass, and negligence provide a suitable legal framework whereby private individuals may obtain redress for damages caused by air pollution.

However, since any control through assertion of private rights depends on the willingness and financial ability of individuals to go to court, and, since the control consequences of private actions are at best piecemeal, our population would doubtless suffocate before the problem was sufficiently alleviated by private control. From the standpoint of society as a whole, therefore, the most that can be expected from air pollution control through assertion of private rights is the handling of some instances of air pollution which cannot be or are not yet controlled by public regulation.

\footnotetext{
${ }^{02}$ Martin v. Reynolds Metals Co., 221 Ore. 86, 342 P.2d 790 (1959), cert. denied, 362 U.S. 918 (1960).

${ }^{98}$ Fairview Farms, Inc. v. Reynolds Metals Co., 176 F. Supp. 178 (D. Ore. 1959).

' Renken v. Harvey Aluminum, Inc., 226 F. Supp. 169 (D. Ore. 1963).
} 